\title{
THE RELATIONSHIP BETWEEN EMOTIONAL INTELLIGENCE AND STUDENTS ENGLISH ACHIEVEMENTAT X MIA AND IIS OF SMA NEGERI 8 BENGKULU
}

\author{
Novita Sari \\ University of Bengkulu \\ sari56586@gmail.com \\ Bambang Suwarno \\ wdsaraswati@gmail.com \\ University of Bengkulu \\ Dedi Sofyan \\ Dedisofyan73@gmail.com \\ University of Bengkulu
}

\begin{abstract}
The aims of this research were to find out the relationship between students' emotional intelligence scores and theirEnglish achievement scores.This research applied a correlational design. The population consisted of the students' of SMA Negeri 8 Bengkulu while the sample comprised 70 students'. The data were collected from two instruments, namely, a questionnaire to collect the data on students' emotional intelligence and a teacher's score list to collect the data on their English achievement. There was a correlation between students' emotional intelligence scores and their English achievement scores. However, the coefficient of correlation was 0.261 and it was categorized as 'low'. Keywords: Emotional intelligence, English achievement
\end{abstract}

\begin{abstract}
Abstrak
Tujuan dari penelitian ini adalah untuk menemukan hubunganantaranilai kecerdasan emosional siswadanuntuk mengetahui nilai prestasi bahasa Inggris. Penelitian inii menggunakanrancangankorelasional. Populasimencangkup siswa di kelas sepuluh SMA Negeri 8 Bengkulu, dengan 70 siswa sebagai sampel. Data di kumpulkan dari dua instrument, yaitu: angket untuk mengumpulkan data pada kecerdasan emosional siswa dan daftar nilai guru untuk mengumpulkan data pada prestasi bahasa Inggris. Hasilnya, ditemukan bahwa ada hubungan antara kecerdasan emosional siswa dan prestasi bahasa Inggris. koefisien adalah 0.261 dan tergolong dalam kategori 'rendah'.
\end{abstract}

Kata Kunci: Kecerdasaan emosional, Prestasi belajar bahasa Inggris siswa 


\section{INTRODUCTION}

School as formal institution is a place to achieve the goal of education. Through the school, students learn many things. In formal education, study shows the changes that are positive so that at a later stage the skills, expertise and new knowledge will be obtained.The results of the learning process are reflected in academic achievement. However, in order to achieve satisfy academic achievement, the students need a learning process.

Learning process that occurs in individual was an important thing, because through studying, individual was familiar with their environment and tried to adapt the surrounding environment. According to Irwanto (1997) learning is a process of change has not been able to be able and occur within a specified period. By learning, students can realize ideals expected.

In the process of teaching and learning in schools, frequently there were students who cannot achieve equal learning achievement with their intelligence capabilities. There were students who had high intelligence capability but earned relatively low learning achievement. While, there were students who despite has relatively low intelligence capabilities but can achieve relatively high academic achievement. That was why the level of intelligence was not the only factor that determined the success of a person, because there were any other factors that influence. According to Goleman (2016), intelligence quotient (IQ) only accounted for $20 \%$ of our success, while $80 \%$ is the contribution factors other forces, such as emotional intelligence or Emotional Quotient (EQ), the ability to motivate, overcoming frustration, impulse control, set the mood (mood), empathy and the ability to work together.

In the process of student learning, the intelligence was indispensable. IQ cannot function properly without the participation of emotional appreciation of the subjects presented in school, but usually the intelligence is complementary. The balance between IQ and EQ is the key to success for students at school (Goleman, 2016). Education in schools was not only necessary to develop rational intelligence, but also need to develop emotional intelligence students.

Based on researchers observation on one-month teaching practice or internship 3 at SMAN 8 Bengkulu, researcher found that the academic achievement in the school was generally good. Besides that, the learning situation had been created well. Many facilities which used to support learning process were available, such as free internet connection, library, science laboratory, music room, and the other facilities.

The researcher experience in teaching at that school, researcher taught one class of MIA and two classes of IIS. MIA is mathematics and natural science, while IIS is the social sciences. The researcher found that there were significant differences in students learning. The students of $X$ MIA have high motivation to study, it can be seen from the students participation in learning process. Most students' were active in learning process, they were eager to ask and answer the question from the teacher. Unfortunately, most students of X IIS had low motivation to study, there were many students who came late and did not make the assigments. Also most students of $\mathrm{X}$ IIS have low score in mid-test and final test. Based on that experience, the researcher concluded that there was another factor which influences students in learning. The researcher guesses that factor was emotional intelligence.

According to Yusuf (2004), there are positive and negative emotions. First, positive emotions will affect students to focus on the learning activities, like take notice the teacher's explanations, reading a book, active in discussions, doing task, and discipline in learning. Positive emotions can be same like feelings of 
happy, spirited or curiosity. Second, negative emotions, so the learning process will experience an obstacle. Student cannot focus to learn so that most likely will have failed in their learning. Negative emotions can be unhappy, disappointed and not excited.

Moreover, before conducting this research, there were some researches which are closely related to this research. First, the research was conducted by Guna (2012) who investigated the correlation between Emotional Intelligence and Students' Achievement. The subject of this research was 10th grade in SMA Negeri 3 Salatiga. The result of the correlation test, it could be concluded that there was no correlation between EI and students' achievement. Second, the research was conducted by Azimifar (2013) who investigated the relationship between emotional intelligence and academic achievement. The result revealed no statistically significant correlations between student scores on the SEI-YV and the achievement tests among Iranian students at elementary schools. Both researches had the different result may be due to the different subject of the research. For that reason, the researcher conducted or did a research about the relationship between emotional intelligence and English students achievement.

Based on the explanation above it was found that emotional intelligence and students' achievement had no significant correlation. So, the researcher wanted to investigate whether or not there was a relationship between emotional intelligence and students achievement of High School students in Bengkulu. The researcher conducted a research at the first grade students of Senior High School Number 8 Bengkulu. The researcher also had an access to this School because the researcher have done the internship III there.
The title of this research was "The Relationship Between Emotional Intelligence and Students English Achievement". This research was continuing the study of the relationship between emotional intelligence and English students achievement in order to find out whether or not emotional intelligence had a significant relationship and English students achievement.

Was there any significant relationshipbetween emotional intelligence and English students achievement at X MIA and IIS of Senior High School Number 8 Bengkulu?

\section{METHOD}

This study employed a quantitative correlational design. According to Arikunto (2010), quantitative research is an attempt to investigate an issue by using numerical data and statistical processing In this study, there were two quantifiable variables. First, Emotional Intelligence whose variable was an independent one (X). Second, English students achievement whose variable is a dependent one (Y). The degree of relationship between the two variables was known by calculating product moment correlation coefficient.

The population of this research consisted of 6 classes of Senior High School Number 8 Bengkulu in academic year 2016/2017. The total was 6 classes: 3 classes majoring MIA and 3 classes majoring IIS. Total of population is 200 students.

Arikunto (2010) stated that if the population is less than 100 respondents, it is better for the researcher to take all of the population as sample. Meanwhile, if the population is more than 100 respondents, the researcher may take $10-15 \%$ or $20 \%$ $25 \%$ from the total population as sample. In this research, the researcher took $35 \%$ from the 200 population as the sample. The total sample was 70 students.

There are 60 items that will be used in this questionnaire, the items divided into 2 . 
First, favorable (positive) items consisted of 30 , and second, unfavorable (negative) items consisted of 30 also. The items of the questionnaire were developed based on 5 aspects (Goleman, 2016). There were about self awareness, emotional management, self motivation, empathy and social skills. Technique to get the data were taken from first semester total grades in students' book reports, only scores English students'.Examples of questionnaire items were as follow:

Table 1. Questionnaire

\section{VO : VERY OFTEN \\ O : OFTEN \\ $\mathrm{N}$ : NEUTRAL \\ S : SELDOM \\ R : RARELY}

Pearson product moment correlation was used to investigate whether or not there was a significant correlation between Emotional Intelligence and English students achievement. The correlation calculation was done by using SPSS software version 16.00.The result of calculating $\left(r_{\text {count }}\right)$ was compared to $r_{\text {table }}$ in

\begin{tabular}{|c|c|c|c|c|c|c|c|}
\hline $\mathrm{NO}$ & Statements & VO & $\mathrm{O}$ & $\mathrm{N}$ & $S$ & $\mathrm{R}$ & order to know which hypothesis was \\
\hline 1. & $\begin{array}{l}\text { I keep learning } \\
\text { though no } \\
\text { examination. }\end{array}$ & & & & & & $\begin{array}{l}\text { accepted and which was not. } \\
\qquad r_{x y}=\frac{n \sum X Y-\left(\sum X\right)\left(\sum Y\right)}{\sqrt{\left\{n \sum X^{2}-\left(\sum X\right)^{2}\right\}\left\{n \sum Y^{2}-\left(\sum Y\right)^{2}\right\}}}\end{array}$ \\
\hline 2. & $\begin{array}{l}\text { I will keep } \\
\text { trying to get the } \\
\text { best values } \\
\text { among my } \\
\text { classmates. }\end{array}$ & & & & & & $\begin{array}{l}\text { rxy }=\text { the correlation } \\
\text { coefficient between } X \text { variable and } \\
Y \text { variable } \\
n=\text { the number of the subject } \\
\Sigma x=\text { the sum of all the } x \text { variable } \\
\Sigma y=\text { the sum of all the y variable } \\
\Sigma x y \quad=\text { the sum of each } x\end{array}$ \\
\hline 3. & $\begin{array}{l}\text { I always greet } \\
\text { the teacher } \\
\text { when I meet } \\
\text { them. }\end{array}$ & & & & & & $\begin{array}{l}\text { variable multiplied its } \\
\text { corresponding y variable } \\
\Sigma(\mathrm{x})^{2}=\text { the sum of squares of the } \mathrm{x} \\
\text { variable } \\
\Sigma(\mathrm{y})^{2}=\text { the sum of squares of the } \mathrm{y} \\
\text { variable }\end{array}$ \\
\hline
\end{tabular}

RESULTS AND DISCUSSIONS Result

Table 2. Row Scores

\begin{tabular}{|l|c|c|c|c|c|}
\hline No & X & Y & No & X & Y \\
\hline 1. & 164 & 80 & 30. & 139 & 77 \\
\hline 2. & 159 & 76 & 31. & 139 & 75 \\
\hline 3. & 159 & 76 & 32. & 138 & 78 \\
\hline 4. & 155 & 75 & 33. & 138 & 75 \\
\hline 5. & 155 & 75 & 34. & 138 & 75 \\
\hline 6. & 154 & 78 & 35. & 138 & 75 \\
\hline 7. & 151 & 83 & 36. & 137 & 75 \\
\hline 8. & 151 & 81 & 37. & 137 & 77 \\
\hline 9. & 151 & 76 & 38. & 136 & 72 \\
\hline
\end{tabular}
not fulfilled

6. I do not have a target in learning.

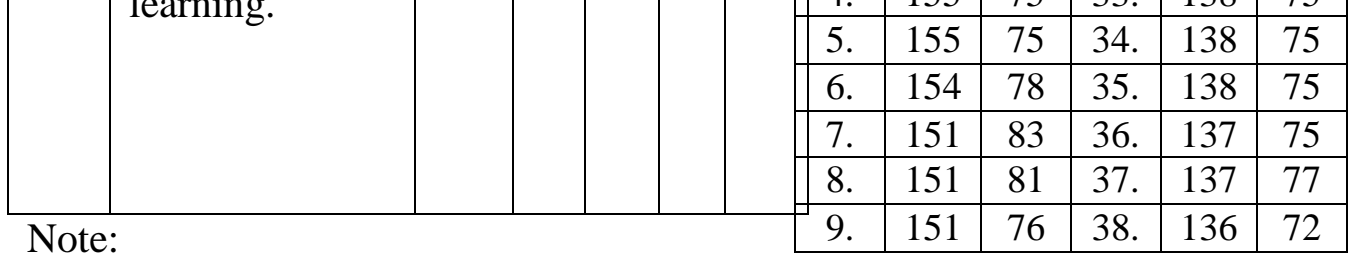




\begin{tabular}{|c|c|c|c|c|c|}
\hline 10. & 150 & 78 & 39. & 135 & 77 \\
\hline 11. & 149 & 75 & 40. & 134 & 77 \\
\hline 12. & 149 & 76 & 41. & 133 & 77 \\
\hline 13. & 148 & 80 & 42. & 133 & 77 \\
\hline 14. & 148 & 76 & 43. & 133 & 77 \\
\hline 15. & 146 & 75 & 44. & 133 & 76 \\
\hline 16. & 146 & 75 & 45. & 133 & 75 \\
\hline 17. & 145 & 77 & 46. & 132 & 81 \\
\hline 18. & 145 & 71 & 47. & 132 & 78 \\
\hline 19. & 144 & 81 & 48. & 132 & 77 \\
\hline 20. & 144 & 77 & 49. & 132 & 75 \\
\hline 21. & 143 & 75 & 50. & 131 & 78 \\
\hline 22. & 142 & 78 & 51. & 130 & 81 \\
\hline 23. & 142 & 76 & 52. & 130 & 80 \\
\hline 24. & 142 & 75 & 53. & 129 & 81 \\
\hline 25. & 141 & 78 & 54. & 129 & 78 \\
\hline 26. & 141 & 76 & 55. & 129 & 75 \\
\hline 27. & 141 & 75 & 56. & 128 & 75 \\
\hline 28. & 140 & 75 & 57. & 126 & 75 \\
\hline 29. & 139 & 78 & 58. & 126 & 72 \\
\hline 59. & 126 & 78 & & & \\
\hline 60. & 125 & 81 & & & \\
\hline 61. & 124 & 78 & & & \\
\hline 62. & 123 & 78 & & & \\
\hline 63. & 123 & 78 & & & \\
\hline 64. & 123 & 75 & & & \\
\hline 65. & 122 & 78 & & & \\
\hline 66. & 121 & 81 & & & \\
\hline 67. & 120 & 78 & & & \\
\hline 68. & 117 & 75 & & & \\
\hline 69. & 112 & 75 & & & \\
\hline 70. & 111 & 75 & & & \\
\hline
\end{tabular}

Note:

Score of Emotional Intelligence (X) Score of English Students Achievement (Y)

Table 3. Correlational Analysis

\begin{tabular}{|l|l|l|}
\hline & $\begin{array}{l}\text { Score of } \\
\text { Emotional } \\
\text { Intelligenc } \\
\text { e (X) }\end{array}$ & $\begin{array}{l}\text { Score of } \\
\text { English } \\
\text { Students } \\
\text { Achievemen } \\
\mathbf{t}(\mathbf{Y})\end{array}$ \\
\hline $\begin{array}{l}\text { Score of } \\
\text { Emotional } \\
\text { Intelligence } \\
\text { (X) } \\
\text { correlation }\end{array}$ & 1 & 0.261 \\
& & 0.000 \\
\hline
\end{tabular}

\begin{tabular}{|l|l|l|}
\hline Sig.(2-tailed) & 70 & \\
$\mathrm{~N}$ & & \\
\hline $\begin{array}{l}\text { Score of } \\
\text { English } \\
\text { Students } \\
\text { Achievemen } \\
\text { t (Y) }\end{array}$ & 0.261 & 1 \\
correlation & 70 & 70 \\
Sig.(2-tailed) & & \\
N & & \\
\hline
\end{tabular}

Thecoefficientcorrelation between the two variables $r_{\text {count }}(0.261)>r_{\text {table }}$ (0.235) with the degree significance of $5 \%$. It meant that the null hypotheses $\left(\mathrm{H}_{0}\right)$ was rejected and the alternative hypotheses $\left(\mathrm{H}_{1}\right)$ was accepted. Based on five categories of correlation strength (see Table 3.7), the degree of correlation was categorized as weak, which meant that there was a correlation between the two variables was in 'low' level.

\section{Discussion}

The result from the researcher calculation of the two variables calculated by SPSS Version 16.00 was shown in the table 3. Based on the result, it can be said that the emotional intelligence influence the students' English achievement. However, the correlation between students' emotional intelligence and English achievement is in 'low 'level.

At the beginning of this research, the researcher assumed that there will be positive correlation between students' emotional intelligence and their English achievement scores. However, the result revealed the negative result which is far away from researcher's assumption. The negative result of this research could be caused by some reasonable factors. Since emotional intelligence is a factor among many other factors which can influence 
students' English achievement scores, it could be assumed that emotional intelligence only gives little impact in students' English achievement scores. In this case, probably the students' of SMA $\mathrm{N} 8$ Bengkulu are influenced by other factors in enhancing their English scores, such as; motivation, healt, and etc. According to Walgito (2004) there are two factors which influence the students scores. They are internal factors and external factors. Internal factors are physical factors, psychological factors, and exhaustion factor. Meanwhile, external factors are family factors, school factors, and evironment factors.

Comparing this present research to the previous researches, there are some previous researches which are in line with this presents research, though the variable of the previous researches were different, such as academic achievement, language learning, and general achievement. The first previous research come from Azimifar (2013) it was found there was no statistical significant correlation between students scores on the SEI-YV and the achievement tests among Iran students' at elementary schools. The second previous research was in line with the present research. It was conducted by Ghanadi (2014), with the result that there was a positive and significant relationship between emotional intelligence and leraners' beliefs about language learning.

This research result was different from Guna (2012) that used the different subject, method, and school to find emotional intelligence and their achievement. He found in his research that there was no correlation between emotional intelligence and students' achievement in SMA N 3 Salatiga. Meanwhile the results of the present study showed that there was a correlation but it was not signifi cant and linear.The results of the presentstudy showed that low score of emotional intelligence does not automatically mean that the student will get low score ofEnglish achievement and high score of emotional intelligence does not always indicate that the student will also get high scorefor English achievement.

The strength of this research was this research was more complete because the sample of this research was taken from all classes of tenth grade that divided into natural science and social science classes. Meanwhile, the limitation of this research was the correlation between emotional intelligence and English students achievement was limited into simple correlation, while multiple correlations were not performed.

The result of this research can be used as the references for English teacher in teaching in the classroom. The teacher should consider the students' need in learning English and also create good emotional intelligence in the class by keeping good communication and interaction to students, applying good learning styles and making the class becomes more comfortable.

For the further researcher that will conduct the research in the same term, the correlation between emotional intelligence and English students achievement. The further researcher can elaborate the focus of the study. In this research, the emotional intelligence was only focused on the personal interaction between teacher and students or among the students themselves, and the learning process. Besides that, the further researcher can conduct this research for other grade and also in different location. This research was conducted in senior high school, so the further researcher can conduct this research in vocational school. Also the further researcher can focus on integrative and instrumental emotional intelligence and do multiple correlations for each aspect. 


\section{CONCLUSION AND SUGGESTIONS}

Based on the result of the research that was described in the previous chapter, the researcher concludes that:

1. There was a correlation between emotional intelligence and English students' achievement at $\mathrm{X}$ natural science and social science classes of SMAN 8 Bengkulu city. It can be proved by $r_{\text {count }}(0.261)>r_{\text {table }}(0.235)$ in the $5 \%$ degree. However, the correlation was 'low' but the alternative hypothesis $\left(\mathrm{H}_{1}\right)$ was accepted while null hypothesis $\left(\mathrm{H}_{0}\right)$ was rejected. Based on that result, it could be concluded that there was a correlation between emotional intelligence and English students achievement.

2. The students' emotional intelligence at $\mathrm{X}$ natural science and social science of SMAN 8 Bengkulu city was categorized into often category with the grand total of mean was 19.96 and the grand total of average 3.99 .

3. The students' score in English subject at $\mathrm{X}$ natural science and social science of SMAN 8 Bengkulu was 8 students got very high achievements (11.43\%) and 62 students got high achievements $(88.57 \%)$.

In short, there was a correlation between students' emotional intelligence and their English achievement, but the correlation was 'low'.Based on the research results, the researcher would like to give some suggestions as follow:

1. Practical Contribution:

a. For the teacher, this research will give the feedback about how importance of emotional intelligence to their students, so that the teacher can consider the factors of students emotional intelligence in lesson plan, especially on English subject. The teacher also can give the feedback, understand and develop the students emotional intelligence in improving English achievement.

b. For students, this research will be expected to improve their emotional intelligence that can increase their English learning achievement which is informed by the teacher.

c. For researcher, as a reference to the other researchers who wants to conduct further study about the relationship between emotional intelligence and English students achievement. The further researcher can try to conduct this research in different subject and location such as in vocational school and also try to conduct this research by using different method like experimental research.

2. Theoretically, this research is expected to help in identifying the relationship between emotional intelligence and English students' achievement.

\section{REFERENCES}

Arikunto, S. (2010). Prosedur Penelitian:Suatu pendekatan praktek. Jakarta: Rineka Cipta.

Azimifar, M. (2013). The Relationship between Emotional Intelligence andAcademic Achievement among Iranian Students in Elementary School. European online journal of natural and sciences, 2(2) 216-222.

Goleman, D. (2016). Kecerdasan emosional. Jakarta. Gramedia Pustaka Utama. 
Goleman, D. (2015). Emotional intelligence. Penerjemah: T. Hermaya. Jakarta: PT Gramedia Pustaka Utama.

Ghanadi, Z. (2014). The Relationship between Emotional Intelligence and Learners' Beliefs about Language Learning: Iranian Advanced EFL Learners in Focus. Theory and Practice in Language Studies, 4(3)518-523.

Guna , N. A. (2012). The Correlation Between Emotional Intelligence and Students' Achievement (A study on the first year students of SMAN 3 Salatiga). Thesis.

Nurdin. (2009). "Pengaruh Kecerdasan Emosional terhadap Penyesuaian SosialSiswa di Sekolah." Jurnal Administrasi Pendidikan (Nomor 1 VolumeIX). Hlm. 104.

Sugiyono. (2010). Metode Penelitian Pendidikan (Pendekatan KuantitatifKualitatif dan $\mathrm{R} \quad \& \quad \mathrm{D})$. Bandung. Alfabeta.

Salovey, P., \& Mayer, J. P. (1998). Emotional intelligence. In Motallebzadeh, K.(2009). The Relationship between the Emotional Intelligence of Iranian EFL Learners and Their Reading Comprehension and Structural Ability. Journal of Teaching English as a Foreign Language and Literature, 1(4) 39-55.

Walgito, Bimo, 2004. Pengantar Psikologi Umum, Andi, Yogyakarta.
Yahya, A. (2012). The impact of emotional intelligence elemant on academic achievement. 65(4). 